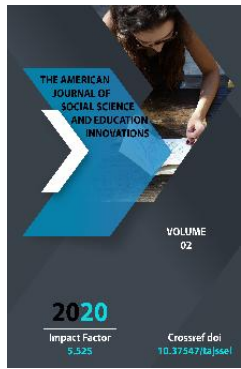

Journal Website: http://usajournalshub.c om/index,php/tajssei

Copyright: Original content from this work may be used under the terms of the creative commons attributes 4.0 licence.

\section{Station And Recompense Elimination: The Collision Of 'Brutal 'Recompense On The Enlightening Foison In The Individualism Of The Nigerian Offspring}

\author{
Toyin 0. \\ School of Media and Communication, Pan-Atlantic University, Lagos, Nigeria \\ Olukayode \\ School of Media and Communication, Pan-Atlantic University, Lagos, Nigeria
}

\title{
ABSTRACT
}

Erik Erikson's hypothesis of the psychosocial formative phases of people, uncover the delicacy of youngsters with exceptional thoughtfulness regarding their natural and psychosocial portrayal. The juvenile age is where the youngster is brave, inquisitive and anxious to investigate, as he gets intrigued with the media and starts to evaluate practices and ways of life of his sentiment chiefs. The Nigerian youngster is pretty much enchanted about unfamiliar films, shows and melodic recordings portrayed by viciousness, thuggery, gangsterism, drug misuse, profanity, and even wantonness which are here and there a lot of data for him to deal with given his creating, youthful and delicate brain science which makes it simple for these substance to impact his conduct in each phase of his character advancement as he is presented to them.

\section{KEYWORDS}

Nigerian Child; Aggression; Personality advancement; Television, Censorship; Violence; Catharsis; Psychology; Society

\section{INTRODUCTION}

As per Sokol (2009), Erik Eriksson was one of the main analysts to propose a life expectancy hypothesis on the improvement of people which incorporate eight psychosocial formative stages with each stage related with a natural clash or emergency that the individual must experience and effectively resolve before continuing to the following stage in their turn of events. To Eriksson, the human life goes through an eight-phase formative cycle which is basic to the general development and advancement of the character of the person. Nonetheless, Eriksson zeroed in on immaturity which is the principle essence of which this paper is based on. To Eriksson, the high schooler years are in reality a period of defining moment of expanded weakness and uplifted potential 
(Eriksson, 1968). The youngster knows about the possibilities he has thus now he needs to test and learn new things. Fleming (2004) cautions that youngsters ought not just realize what their identity is, yet that they should figure out how to characterize and concoct themselves. This is the reason characters are evaluated like new suits of garments with the end goal that guardians, educators, famous people and lawbreakers become good examples for these adolescent kids; contingent upon who the youngster collaborates with frequently or who he holds dear as that individual turns into a persuasive individual to the young person. In a period where admittance to data isn't advanced science, and adolescents nowadays own refined mechanical assemblies like: cell phones, tablets, PCs different gadgets that give them simple survey to any data at some random time, one could just think about what sort of data is accessible and gets expended regularly by youngsters.

Hypothetical Frameworks

Improvement Theory Erik Erikson's psychosocial character advancement hypothesis believes that the advancement of the psychosocial character of the youngster, are in formative stages, and each stage is basic on account of the associations and affinity the kid has at that point. Whoever has more cooperations with the kid at that point will in general impact the conduct and character of the youngster. The youngster years or juvenile years are critical years since it is where the adolescent has expanded weakness and uplifted potential (Eriksson, 1968), thus the young adult is anxious to know things and starts to evaluate characters like new suits. During this period, the adolescent's good example could be guardians, instructors, superstars or even lawbreakers. In light of the approach of data innovation, youngsters and teenagers these days approach Too Much
Information on account of the presence of the web and the World Wide Web. The truth of today is that youngsters own advanced mobile phones, tablets, PCs and other modern gadgets which award them simple admittance to any sort of data, at some random time at practically zero expense. Radio, STATION, paper and magazines have been united on the web to such an extent that with a PDA or any modern gadget they can ride the net, download motion pictures, stream shows, understood papers and magazines and tune in to online radio broadcasts and musicals with almost no expense. Subsequently, it has truly gotten simple for adolescents to get a wide range of media recompense themselves since the approach of the web.

\section{HOSTILITY THEORY}

In the hostility hypothesis, introduction to rough Station substance can trigger a brutal or forceful conduct (Bandura, 1971). From his test perceptions on youngsters, Bandura found that kids are profoundly affected by what they see. In the event that they devour rough substance on STATION, there is an inclination that they are likely going to be savage by rehearsing what they have seen on Station. Therapy Theory

In the therapy hypothesis, presentation to rough STATION recompense, as opposed to spur one to become vicious can really cleanse out those brutal and forceful practices and feelings in kids. The therapy hypothesis is a direct inverse of the hostility hypothesis, and it contends that introduction to vicious STATION substance can't trigger or cause a kid to get brutal in light of the fact that those forceful and rough feelings are cleansed out. Like the kid saw in Bandura's bobo doll analyze, a few kids can really fear viciousness and animosity by watching fierce substance 
on STATION. At the point when a youngster sees the risk of brutality and hostility, as per the therapy hypothesis the kid may not want to show fierce and forceful practices since these desires are cleansed out. This likewise assists with molding the character of the youngster as he grows psychosocially.

\section{ESSENTIAL CONSTRUCTS}

\section{STATION}

The US Federal Communications Commission (2003), portrays STATION as an innovation that performs three fundamental capacities which incorporate changing over pictures and sounds into electronic signs, imparting these signs from the first highlight a collector (otherwise called a STATION) and afterward changing over the electronic signals once more into pictures and sounds. With this portrayal, STATION is a general media gadget that sends pictures or pictures (video) and sounds (sound) utilizing electromagnetic signs into a recipient that is prevalently alluded to as a STATION. Since its creation in the early piece of the1950s, it has become a basic aspect of the American culture and way of life (Pisharody, 2013). STATION has created and its innovation has changed since 70 years prior when it was established by John Logie Baird's mechanical output framework. Today STATION utilizes profoundly modern and progressed mechanical frameworks to send rich engaging, instructive and educative substance over rebranded STATIONs or recipients. Today, STATION exist in further developed structure like savvy STATIONs, LED, and plasma.

Oversight

Lessig (1999) characterizes oversight as the purposeful activity to stop, quiet or oblige opposite or dubious perspectives. Control is commonly perceived to be the official concealment or disallowance of types of articulation (Moore, 2013). Steward (1997) expressed that oversight should be possible in two different ways: State restriction or Private control. In State oversight, it is the administration of the country that disallows the transmission and media utilization of substance on the media. For instance, in the early press in the UK, where the Authoritarian hypothesis of the press applied, the press was edited as there were no advancement and opportunity in the utilization of the media to send data among each other. Individuals were restricted from having free admittance to the media. This is likewise inseparable from the situation of the Soviet regularizing hypothesis which sets that the media should serve the enthusiasm of the gathering, as any data that isn't in consonance with the Soviet party is controlled (Benson, 2008). In Nigeria today, government blue pencils substance on STATION through its administrative offices like the National Broadcasting Commission (NBC) 35 and the Broadcasting Organization of Nigeria (BON).

\section{The Traditional Role of Television as a Form of Media}

STATION has been distinguished as a general media innovation that changes over casings of pictures and sounds into electromagnetic signs, which is handed-off through a transmitter to a collector otherwise called a STATION. As a customary type of media, STATION is the most grounded of the apparent multitude of types of media. This is on the grounds that it manages two significant faculties which are: sight and hearing, while different types of media manage one sense. Since STATION has this favorable position over different types of media, there is no uncertainty that it is an amazing instrument for correspondence. 
Lasswell (1948) distinguished three elements of the media, which include:

The Impact of "Savage" Recompense on the Personality of the Nigerian Child

Moeller (1996) recognized that accessible writing proposes that the substance of STATION can have four wide sorts of impacts on individuals. They incorporate conduct, mentalities, convictions or qualities, and information or intellectual aptitudes. Nigerian youngsters like other kids learn by collaborating with substance on STATION. Hollywood blockbuster activity motion pictures which appear to be one of the fundamental STATION substance devoured by the contemporary Nigerian youngster seems to impact their psychosocial conduct mechanics as these films store arrangement of remarkable pictures or edges in the subconscious personalities of the Nigerian kid. These casings manufacture hills on the subliminal of the present young people who will in general permit the edges to impact their practices as they accept that acting "improperly" brings a term called "loot" that is inseparable from the ways of life of superstars. There are a few examinations that have been completed to demonstrate that introduction to savage STATION substance can impact brutal practices among kids or adolescents who watch them. The soonest of these investigations was the Bobo Doll Experiment did in 1961 and 1963 by Albert Bandura.

\section{DISCUSSION}

As prior expressed, STATION is the most impressive and persuasive type of media due to its feeling of sight and hearing since it is a general media gadget. It could affect the psychosocial improvement of the character of any kid particularly one who is constantly snared to a STATION. With the world rapidly turning into a worldwide town, it is no longer news that mechanical progression has made life very simple, as savvy gadgets and PCs have been imagined to give brisk and simple admittance to any data in any configuration (video, sound, text, illustrations and pictures) at some random time civility of the web. While this mechanical radicalisation could be viewed as an achievement in the simple securing of data, the issue of control turns out to be obviously stressing as these savvy gadgets give the Nigerian kid boundless admittance to Too Much Information (TMI) which could be dangerous, as they will in general let what they are presented to impact their practices, perspectives and characters. From the examinations talked about and assessed here, there is proof to demonstrate that savage STATION substance can impact vicious and forceful conduct in kids: a speculation verified in Albert Bandura's Bobo Doll Experiment dependent on the social learning hypothesis, just as different works led around the world and in Nigeria.

\section{CONCLUSION}

After altogether assessing some optional information and widely auditing related writings of past works in this subject, this paper relied on two significant speculations have shown that in fact adolescent introduction to fierce STATION substance impact the psychosocial advancement of the character of the Nigerian kid as he associates with his condition. Sadly, globalization has made data effectively available with the end goal that the Nigerian youngster devours music, recordings, sound, text and graphical pictures with solid grown-up topics (an excess of data) on STATION. It is thus this paper along these lines suggests that: 
- Brutal STATION messages ought to be edited to control the improvement of the character of the Nigerian youngster.

- Parents should give more educative substance on the gadgets of their wards to fill the hole that forceful substance are presently filling. These substance can assist with embellishment their character in a superior manner as opposed to letting vicious substance with other solid grown-up subjects assume control over their mind and control their activities.

\section{REFERENCES}

1. Vottomore, Kom. 1995. Nigerian Television Authority. STATION Journal (1995). Youth animosity in Ogun state, Nigeria: Fallout from vicious films appearing. Sociologies, 141-146.

2. Kourdieu, 1999 Subjects and strife of Nigerian home video motion pictures . Unilag Personality and Social Psychology, 586-591.

3. Kandura, K. (1991). Social learning hypothesis. New York: General learning press.

4. Kandura, K. (1997). Social learning hypothesis. Englewood Cliffs: Prentice Hall. 